\title{
Women' Struggle for Legal Empowerment in Pakistan Historical Overview
}

Naveeda Noreen (Corresponding author)

Department of Political Science

The Islamia University of Bahawalpur, Pakistan

Prof. Dr. Razia Musarrat

Chairperson, Department of Political Science

The Islamia University of Bahawalpur

Bahawalpur, Pakistan

Accepted: March 27, 2014

doi:10.5296/ jpag.v4i1.5460 URL: http://dx.doi.org/10.5296/ jpag.v4i1.5460

\begin{abstract}
Pakistan is a democratic country, wherein women comprised half of its population. The plight of women rights in Pakistan is not satisfactory, but with the pace of time, the process of legal empowerment for women is in progression. The enforcement of laws lead towards safeguarding women rights more, which culminated into protection of women in a better way. In this study, the process of legal empowerment and protection of women rights has been evaluated in historical perspective. Women are fighting for their rights since colonial period. After creation of Pakistan, women are struggling for attaining more and more legal protection and empowerment. Laws are the reflection of the values of society. The military rulers who were always in quest of legitimacy repealed the laws to safeguard their own interests, which lessened the efficacy of these laws towards protecting women rights. The modernization of the society and awareness among the women compelled the elected Governments to take steps to repeal the discriminatory laws even Hadood Ordinance and honor killings. In Pakistan the lives of the women are governed more by the customs and values rather statutory laws. There are many factors responsible for the poor protection of women rights, lack of education, rigid values system, absence of proper implementation of the laws and complex judicial system.
\end{abstract}

Keywords: Empowerment, dissolution, safeguard, colonialism, awakening, legal 


\section{Introduction}

To trace the status of women in a historical perspective is quite complex because whatever history shows us about women in societies, is derived from the male sight. This paper attempts to present a historical overview of the reform being introduced throughout the history about women' and affects of these reforms on them. The journey towards the empowerment of women cannot be understood unless we understand the their place in ancient society and how these issues were being handled by the higher authorities to protect them and provide them an umbrella in the name of legal reforms in the patriarchal society. Women were being oppressed for centuries due to the patriarchal mind set of society. The gradual process of women uplifting in society, governmental policies towards it and the role of law is being evaluated and discussed.

\section{Women Awakening under Colonial Rule}

Women's struggle for their empowerment has a long history. In the subcontinent 'Hindues and Muslims were living together for centuries but never intermingled in each other. The women question of women rights was being raised throughout this period. Although we read about women in history who were brave and remained outstanding administrators like Chand Bibi, Noor Jahan and many more. (Meena,2008,p.28). In the Mughal' period women of upper class were indulged in different creative activities like art, literature and fine arts. They got education according to availability of time, But these examples were found only in elite and wealthy families. The overall plight of women was not good and the educational opportunities were very rare. In the nineteenth century when Britishers invaded subcontinent' the British writers began writing on the social customs and cultures of this land regarding women(Forbes,1998,P.13). In this century, social, political and technological change was seen in Europe, So to prove their domination on moral grounds they started working on the status of women which were the weaker sex of society. James Mill wrote "History of British of India" and argued that the position of women could be used as an indicator of society's advancement. Although Britishers have their own interests in the advancement of women of this land (Forbes, 1998, P-13). In the subcontinent Britishers were trying to prepare a class of workers who could be beneficial for them to communicate with other masses and helped them to legitimize their rule. They offered educational reforms to people. Now in the nineteenth century there emerged a class who could speak English and was working in the offices as clerks and the assistants of British officers. During this period women were being excluded from higher level education due to the custom of purdha(Shaheed,1990,p.6).Colonial rule upset the educational structure of India. The progressive Anglicization of administration totally changed the values of education from skill to a basic need. After the war of independence in 1857 the position of Muslims totally changed. Educated Muslims became illiterate due to the changes in syllabus and language. There were people who did not want to acquire foreign education and considered it a sin and an attack on their religion and culture to get western education (Shaheed, 1990,p.6). It was Sir Sayyad Ahmad Khan's Ali Garh movement which brought Muslims on the platform to get western education because it was the need of time to get education for their survival. The Hindues had adopted the culture and education of Britishers and a frequent change had come 
in the general attitudes and position of Hindues(Salahuddin,2005,P.54). Sir Sayyad Ahmad Khan did not touched the women related issues. He was of the view that women education is not important process of Muslim development. However the reformative movement of this century strengthened the views of Muslims that educated women could play a positive role in social awakening and economic development of the Muslims. In the meeting of All male Mohammadan Educational Congress (MEC) in 1886 the issue of Muslim women's education was first raised(Shaheed,1990,p.7). The period of 1886 to 1917 was the progressive rethinking period towards the role of Muslim women. Muslim women's education gradually got popularity particularly in the elite class. In this period there were conservative Muslims who strongly opposed this change but a large number of schools and women organizations were opened in this period. The downfall of the traditional system started to show up. Muslim women rejected old system where they were given traditional roles to play and no education was considered necessary for them (.Mumtaz\&Shaheed, 1987, p.37). Education was seen as a way of looking the control of men over women. Gradually this attitude began to change. In1885 when the Anjuman-e-Himayate Islam (Society for the promotion of Islam) opened schools in Lahore. They played an important role towards the education of women. Although the Anjuman's main goal was the preservation of Muslim culture but at the turn of the century the idea that Muslim women education is necessary, gained strength among Muslims (Mumtaz \& Shaheed, 1987 P.39).

In this period social change entails awareness among women about their rights. Enlightened people were demanding legal reforms to upgrade the status of women of India and facilitate women to take their grievances to courts

(Forbes, 1998, P.13). There were many reformists in the India by the second half of the 19th century. Muslims as well as Hindus reformers showed disapproval about the useless customs regarding women. These reformers focused their attention on female infanticide, polygamy, child marriage, sati, pardha and restrictions on the women education(Forbes,1998,P.18). Now reformist organizations began to emerge in Indian subcontinent. These reformers advocated legislative enactments to preserve the rights of women and to bring change in their lives. In the 19th century women began to get education and during the course of this century the lives and status begin to change towards their actions and growing approval of individualism. The concept of "new women" who were working on modernizing movement that wanted to modify gender relations, goes towards the men and women equality(Murshid,1983,p.)Different reformers struggled to improve the lives of the women in the subcontinent by introducing social and legal reforms. The position and status of women in the subcontinent under British rule became a major issue in19th century. There was pressure on the British government by the reformers both Hindues and Muslims to introduce the legislation which would strengthen the forces of change(Lateef, 1990,p.54). In the Indian subcontinent, however, these were the men who first started to speak about the rights and emancipation of women. There was a long list of men reformers who undertook major efforts on behalf of women. Among Muslim reformers Sheikh Muhammad Abdullah, Altaf Hussain Hali focused on education of girls(Forbes,1998,P.20). By the second half of the century there became a group of reformers who focused their whole attention on the eradication of social 
evils like Sati, Polygamy, female infanticide, pardha, child marriage and the prohibition or women education. With the efforts of these reformers the Hindu widows Remarriage Act was passed in 1856. The ultimate goal of Muslim reformers was the progress of Muslims of Subcontinent. They wanted to upgrade their humiliated position under colonial rule. They were searching for the weaknesses of their defeat and wanted to overcome these weaknesses to build up their strength. In the consequences of these reform movements important advances were made towards the emancipation of women. Legal measures were being introduced to elevate the women status in the society. The custom of Sati and female infanticide were declared illegal(Sen,2000.p.17). In 1860 a law was passed to raise the girls age of marriage to ten. It was considered a big step towards the advancement of women emancipation. Because the marriage system was considered the key to control the women by men. The campaign of nineteenth century against Sati and to favor the widow's remarriage act led reformers to develop a broader legislative agenda through which the forces of social change would be strengthened(Ali, Azra,2000,p.123). In this agenda of reforms the campaign against the child marriage was also included. This campaign helped to pave the way for further legislation in the twentieth century.

\section{Emergence of Women Organizations}

Women got the status of "new woman" who had interests beyond the house hold. In this period women started to communicate with each other outside their homes. They started speaking English as a common language which made possible for women to share across language barriers (Forbes,1998,P.64). They started writing in journals and newspapers about their experiences and grievances. These small meetings converted into organizations. These organizations became the centers of the expression of women opinion.

It was the time in 1896 when Tehzib-e-Niswan a weekly magazine was published. A vast majority of women started writing in the magazine.They started writing about reformative articles which were against the social evils like dowery, superstitions or extravagance. In1905 Maulana Hali payed tributed to women by reciting his poem "Chup ki dad" in all India Muslim Educational Conference.

Rashid-ul-Kheri started publishing magazine "Ismat" and Sheikh Abdullah his monthly "Khatoon" along with a magazine "Humayon" published by Gaiti Ara Begum, all these magazines played a significant role in the awakening of Muslim women (Salahuddin,2005, P.58). Moulvi Sayed Mumtaz Ali and Muhammadi Begum started a news paper with the name of Haqooq-e-Niswan. Through this they advised women of India to form societies for the awareness of women and promotion of education through which all women could gather on one platform(Mumtaz,1981, P.40). These newspapers came to be known as beacon for all women. Women began to organize themselves' define their interests' started to take actions and formed their own organizations. Sir Muhammad Shafi was the man who first started to mobilize the woman of his own family and founded an organization Anjuman-e-Khawateen-e-Islam (Muslim Women Organization) in 1908. The members of this organization met periodically in each other's homes(Mumtaz,1981, P.41).

These members worked on the proposals of spreading education, women rights and social 
reforms under Islam along with Hindu women reformers and also established organizations to get rid from the domination of men and put their own efforts for their emancipation.

Many organizations were set up at national level. Three major organizations like Women's Indian Association (WIA) by Margaret Cousin in 1915, The National Council of Women in India (NCWI), an organization established in 1925 by Lady Tata and the All India Women's Conference (AIWC) 1927 by Margaret Cousin(Basu, \& Bharati; 1990) All these organizations were the indicator of women's awakening.

\section{Legal Reforms during Colonial Period and its Effects on Women's Rights:}

Indian Social reformers were very much concerned with uplifting the status of Indian women. They needed an umbrella of law or legislation to safeguard the rights of women in India. In the nineteenth century, however there were different views about the manner how social change should be brought in the subcontinent(Ali, Azra.,2000, P.123).Any movement for change causes reactions They all were in the favor of change which had become essential for the progress and survival. From 1818 the British settlers had acquired the Bombay presidency and in 1827 Bombay regulation was the first enactment which was applicable to that area. British law replaced customary and religious laws and in criminal laws in which included revenues, evidence, land tenure, theft and adulatory and to some extent the property transfer and all procedural laws(Mumtaz, 1987, P.37). In the colonial period however personal status law was based upon the personal laws of the parties or on the customs prevailing there(Welchman, \& Hossain, 2005,p.81).

The status of women in the subcontinent remained a major social issue during the nineteenth century. Both governments (British and India) were pressured by the Indian reformers to introduce laws which would make the forces of social change strong(Lateef, 1999 P.55). Women were in the forefront on the main agenda of reform movement.

They considered women's emancipation as the precondition to national regeneration and a source to achieve advancement, modernity and civilization. A series of campaigns by these reformers resulted in the enactment of the abolition of Sati in 1829 and in 1856 Widow Remarriage Act was passed through which widows got the legal right to marry again. The period (1890-91) which was named as the age of constant controversy. In this period British government wanted to raise the age of marriage of Indian women. It was a watershed towards the women advancement(Sen,2000,p.13). The Second generation of "New women" began to emerge in the period of 1920s who were more active. They were able to express the requirements of other women. They criticized their society and foreign rulers started to develop institutions and tried to consolidate women's interestsIn the campaign of the Child Marriage Act which was known as the Sarda Bill because the Harbilas Sarda was the head of the committee which was dealing the bill, female Infanticide was the next social evil in the society. In 1870 female infanticide Act was passed to control this evil social activity(Ali, Azra,2000,P.6). The important laws which were modified by customs which continuously were being applied with change by legislative enactments were the Special Marriage Act of 1872. The Married Women's Property Act of 1874, the Divorce Act of 1869. The guardians and wards act of 1890. The Marriage Validation Act of 1892. The Muslim Personal Law 
Application Act of 1937 and the Dissolution of Muslim Marriage Act of 1937(Patel,2010,P.9).The 19th century legislation paved the way for the 20th century legislation. Muslim communities were supporting the laws which were changing customs prejudicial to women. After that they realized that Muslim personal laws under the Sharia can be best served the rights of Muslim women which have been superseded by the traditions and customs. During British rule in the subcontinent of India Muslim's personal laws were mediated through the post of Kazi. British government abolished this post in 1864. The shariat was not enforced fully in that period, however Kazis, who were officially appointed and paid by the government had the ability and authority to lead legal absolution in the cases of marriage, dower, divorce etc .But when this post was abolished by the government ,Muslims would have to consult those Kazis who had no official authority and were not well trained(Hussain,2006,p.3). In 1880 Sayed Ahmad Khan demanded to government for the restoration of the post of Kazi so that the duties to mediate personal laws should be performed on the regulatory bases instead of self appointed Kazis. This caused more hardships to women and left them merciless on the patriarchal culture of male authority.

With the changes in the legal procedure the implementation of women's rights also changed and irregularities came in it. Such as when Married Women Property Act 1876 was enacted so by the second decade of the twentieth century the women reformers demanded to government that there was essential need to get rid of old age traditions, which were creating the barriers in the advancement of women. They were advocating reforms like the franchise and changes in the Hindu personal law which was affecting marriages, family and property rights(Hussain,2006,p.5). Reformers were of the view that there was an urgent need of legal changes for women. Legal changes would remove the miseries of women and would pave the way towards being a progressive state of the world (Forbes,1998,P.113). They were demanding for new personal and family law which would make women independent and play a role in the public life.

Muslim personal law Shariat. They wanted to adopt a position under legislation where there would be no interference in their own personal laws. Muslims already had adopted the Child Marriage Act of 1929. Other measures provoked strong opposition on the grounds that Shariat had already explained rules for these matters (Ali, Azra,2000, P.147). British principles of criminal law superseded Islamic criminal laws. The Indian Evidence Act which was based on English principles had passed rendering the Islamic rules obsolete (Serajuddin, 2011,p.14). After the war of independence Muslims were hardly in the position to object those changes, which had caused the outright rejection of Sharia law in the large area of life. Due to these changes the Muslims were confined to questions relating to family relations and laws, such as marriage, dower, divorce, maintenance, guardianship of children, succession and inheritance, religious usages and institutions and disposition of property by gift, will and wakf. This bill was the response to the laws passed in 1876. Married Women's Property Act, the Indian Succession Act 1885 and Guardians and Wards Act 1890(Serajuddin 2001,p.88).

In 1925 women had got the right to vote but only property holder women got this right this problem solved under the Government of India act under which right to vote was given to sixty million women. They also became able to get six seats in the council and 9 out of 250 
seats of the federal assembly.

\section{Muslim Personal Law Application Act 1937}

Soon after, the Ulemas realized that Muslim women were deprived from their right of share in inheritance and this was the violation of the Quranic commands. The provincial branch of the Jamiat-Ulma-e-Hind took first step towards this step forward. After crossing many steps this law was passed on 10th September as the name of Muslim Personal Law Application Act 1937(Ali, Azra 2000, P.147). In response to the objections and reasons for these acts it may be stated that the status of Muslim women under the so called customary law was simply disgraceful(Patel,2010. P.9). Muslim women organizations were raising their voices against the inequalities of the customary laws through which they were denied to rights which Islam had granted them. Due to that Muslim women were kept in grave economic and social setbacks. This Act provided the ray of sunlight for searching to change the social as well as political status of Indian women(Ali, Azra, 2000. P.152).

\section{Dissolution of Muslim Marriage Act 1939}

Another act that was adopted to Muslim personal law was the Dissolution of Muslim Marriages Act of 1939. Which was exclusively enacted to benefit the Muslim women by picking the most liberal features of the four schools of jurisprudence(Lateef,1990, P.71).

Islam gives the right to Muslim woman to break her marriage if she prejudiced a marriage but there were differences of opinion between the four schools of Islamic law. The Hanafi code of Muslim law did not allow the women to get divorce even in the cases of maltreatment by husbands and who failed to maintain her. Other school of thought was the Maliki which allowed the Kazi to dissolve the marriage of Muslim women on a wide variety of grounds In the early decades of 20th century situation became crucial when Muslim women stated to change their religion to dissolute their marriages. Quran already allows the Muslim women dissolution of a marriage in case of necessity (Mahmood, 1995, p.153).

So this Act sought to solve this problem of the dissolution of marriage to help the Muslim women. Muslim majority in India followed the Hanafi school of Islamic jurisprudence which was very strict towards the divorce of women. The new Act allowed the Muslim women either she was a Hanafi wife to get a divorce on the grounds of cruelty, desertion or maltreatment by the husband. The Muslim Dissolution of Marriage Bill enacted in 1939 after the two years of Shariat Act 1937. These both acts provided a milestone towards the rights of the Muslim women.

All these legal reforms in the subcontinent were the step forward towards the empowerment of women and sense of awareness of their rights. One of the main factor which allow Muslim women to modify or change their lives was due to the effective alliance forged between the two who were working for the Pakistan movement and those who were supporting the women's rights(Shaheed,1990, P.8).

Women had recognized their responsibilities after getting such rights. In 1946 two Muslim women participated in the elections as the candidates i.e Begum Salma Tassaduq Hussain and 
Begum Shahnawaz. These women struggled hard to mobilize the women that they should participate in the movement for their own homeland where they will have a clear guarantee of a secure political, social and legal status.

Muhammad Ali Jinnah became the great leader of the nationalist movement of Muslims in the subcontinent. In his views, the status of Muslim women needed urgent legal reforms which could provide them better protection(Naheed,2008,p.283). Muslim women entered in the vast campaign for Pakistan because they had strong belief that in new homeland their leader will introduce urgent reforms to bring them out of the suppression that they were facing from centuries.

Quaid-e-Azam Muhammad Ali Jinnah focused his attention towards women and welcomed them to participate in the Pakistan movement. He pointed out deplorable women oppression in many of his speeches. At Aligarh in 1944 he said(Mumtaz, \& Shaheed, 1987, P.7).

"It is a crime against humanity that our women are shut up within the four walls of the houses as prisoners. There is no sanction anywhere for the deplorable conditions in which our women have to live. You should take your women along with you as comrades in every sphere of life" to prove this he always took Fatima Jinnah with him. He believed in the image of a progressive women(NCBCC,Jinnah,1976,P.vii). He always took counsel of his sister in important decisions. He said in March 1944 "No nation can rise to the height of glory unless its women work side by side with men" (NCBCC,Jinnah,1976, P.45).

\section{Emergence of Pakistan \& Empowerment of Women}

Pakistan emerged on the scene of the earth on 14th August 1947 with countless new hopes and desires. At that time Quaid-e-Azam. said on 24th August 1947 "I call upon every Pakistani Muslim man and women not to be led away by sorrow." They have sacrificed for the formation of their national state. Now it is for them to built it. In this way Quaid called for the women's participation in nation building activities. Our founder was an enlightened Muslim and fully aware that Islam has granted rights and freedom equally to women and men. Women's improvement in their status was closest to his heart (NCBCC, Jinnah, 1976, P.46).

Unfortunately he had not more time to do work for the empowerment of Pakistani women and to introduce legal reforms in which Pakistani women could get rid from the subjugation of male.

In post independent period Pakistan remained practicing pre independence laws. The principles of Muhammadan law had continued into force. Pakistan was also the sweet dream of women as well as men. Enlightened men and women restarted their struggle with more enthusiasm for changes in the personal laws which were based on the customs and traditions.(patel,1979,P.10).

They also demanded to displace the Anglo Muhammadan law which was misinterpreted by the superior courts decisions under British government. Pakistani women who were mobilized during the Pakistan movement and were very much recharged, directed their energy towards the problems which Pakistan was facing right after the birth like the 
problem of settling refugees. They were mostly from the families of leading Muslim League Politicians(Madani, 2005,p.90). Begum Rana Liaquat Ali Khan along with other women started volunteer services like dealing with health problem, food distribution, first aid, clothing and moral support. Women were serving for the new homeland with wholehearted enthusiasm and dreams in their eyes which were near to be fulfilled. When the movement for Pakistan started there was another conservative and religious element which was opposed to the creation of Pakistan because they were not in the favor of empowerment and participation of women (Shaheed, 1990, P.8). Any move for the participation and to promote the status of women was always opposed by these conservative people.

The female members of the National Assembly introduced a bill in 1948 to secure the economic rights of women but this was not passed. Women protested against it and they marched towards National Assembly Chambers which resulted in the approval of Muslim personal law of Shariat which was implemented in 1951 and which recognized the right of women to inherit property including agricultural holdings(Shaheed, 1990, P.9). From independence women had to struggle to obtain their rights and they had to agitate and build pressure on government. Women agitation is mostly found in the legislature. Two women Begum Jahanara Shah Nawaz and Begum Shista Ikram Ullah fought the legislative battle for Pakistan women in the legislature(Mirza,1977,p.4). These two women demanded for the 10 percent quota of reserved seats for women in 1935 at the round table conference, but they only attained 3 percent quota. In 1954 when Begum Shahnawaz prepared the draft bill for the charter of women's rights. In this charter these women demanded equality in all spheres of life like equal pay, equal status, equal opportunities and the guarantee of rights and freedom under the Islamic personal law of Shariat. This charter was passed unanimously by the minorities and Muslims. In the 1956 constitution the principle of female suffrage, for the reserved seats for women and women's territorial constituencies by giving right to vote to women for the reserved and general seats was adopted Women remained struggling for their rights although the number of these women could be counted on fingers but under the leadership of Begum Rana Liaquat Ali Khan, who established All Pakistan Women Association since 1948, fought for the rights of women. This type of struggle can be seen in 1955 when (APWA) launched a campaign against Prime Minister Muhammad Ali Bogra's second marriage. During this campaign(Mirza,1977.p.87). Begum Jahan Ara Shah Nawaz formed united front for women's rights. The act of the Prime Minister's second marriage started agitation against poly gamy. Women started demanding for legal reforms in the Muslim family laws.

\section{Rashid Commission 1951}

The government appointed a commission named as Rashid Commission which submitted its recommendations in 1956(Shaheed,1990,P.9). This commission was appointed due to the pressure from women and women organizations and the continuous demand for the reforms in the family laws so that women rights could be preserved. The Commission was made to bring changes in the marriage and family laws. On 4th August 1955 government of Pakistan constituted a commission which consisted of seven members and named commission on Marriage and Family Laws (1955) in pursuance of a resolution of the ministry of law(Report 
of COSW,2003). The terms for the commission were as follows. Do the existing laws governing marriage divorce, maintenance and other ancillary matters among Muslims require modification in order to give women their proper place in society according to the fundamentals of Islam(Gazette of Pakistan, PP-1197-8. June 20, 1956).

This commission was comprised of three women and five men and they worked under the supervision of the ministry of law. Dr. Khalifa Shuja-ud-Din was appointed as the first president of this Commission but he died only after to hold the first meeting. After his sudden death Pakistan's former Chief Justice Mian Abdul Rashid was appointed as the new President and due to this the Commission is referred to as Rashid Commission. The Commission was advised to report on the proper registration of marriages and divorces and the establishment of special courts which could deal the cases effecting women rights(Gazette of Pakistan, 1956). The Commission conducted a country wide research by a Questionnaire on marriage, divorce, poly gamy, custody of children, mehr, dissolution of marriage by court, maintenance, inheritance and guardianship of property. This questionnaire was printed in both languages Bengali and Urdu. The final report of the Commission published on 20th June 1956 in the Gazette of Pakistan.

Commission enlisted recommendations on Muslim Family law matters and mechanisms for it. The Commission emphasized that the given recommendations are not the new rights to women or out of the spirit of Quran and Sunnah. They added it as the duty of Muslims to make Muslim society progressive and dynamic.

\section{The Muslim Family Laws Ordinance 1961}

The Muslim family laws ordinance 1961 was a very important legislation for Pakistani women and it lead them towards legal empowerment. Before this in the pre-independence period the Dissolution of Muslim Marriages Act 1937 was the important legislation, a change in the marriage law which was related to Muslim women. The1961 marriage law was very comprehensive. Under this law it was suggested that a husband could use his right to divorce only with the consent of the court(Report of COSW,2003,p.2).

Under this law, the registration of marriages became mandatory. It had become a need because the oral evidence was caused to create problems and confusion (MFLO 1961) under section 5 the registration of marriage was made mandatory. This law gave authority to the Union Council to appoint Nikah registrars and it was the duty of the Council to give a register of the Nikahnama in a prescribed form and a seal for the Nikah registrar and the Nikah registrar was bound to give the copies of Nikah to bride and bride groom and a duplicate copy would be forwarded to the union council(Ali,parveen,1979,p.24). In this ordinance the irrevocable triple Talaq had been abolished. Under the section 7 of the Ordinance it was required that any man who wished to divorce his wife shall, as soon as may be, after the pronouncement of Talaq in any form what so ever, give the chairman notice in writing of his having done so, and shall supply a copy to his wife. Who ever deny this provision would be punished which can be extended to one year imprisonment or a fine up to five thousand (Patel, 1979, p.51). 
This Ordinance however in the matter of divorce abolished the traditional and customary practice of declaring the word "Talaq" thrice. Under this ordinance after sending the copy to chairman from the time to 90 days period starts. During this time the arbitration Council was set up to pave the way for reconciliation between the parties. If the period ends then the divorce becomes effective(Patel,1979,p.54). In other condition if the process of reconciliation succeeds the husband took the notice back. However to discourage polygamy was the basic aim of this ordinance. This ordinance stipulates that a man who wanted to make second marriage he would have to obtain the will or consent of his first wife and he will have to give reasons for his second marriage before the arbitration council. The council will make the final decision in this regard. The husband should also have to satisfy the court that he could balance between the two wives and children (Gazette of Pakistan,2 March,1961). In this regard court will monitor that the man who wanted to marry second time is financially capable for supporting two families. Under this ordinance the age of marriage for both girls and boys extended from 14 to 16 and for the boys 18 to 21 respectively. The para added to the ordinance if the wife sues for divorce she should forego her dower, unless some other management has been made between husband and wife(Mumtaz, \& Shaheed,1987, P.38). The aim was to safeguard the women's rights to haq Mehr (dower) helping in view that the amount would be payable whenever demanded, If it is specified in the nikahnama. The authority to settle the disputes given to arbitration council by giving them the jurisdiction to grant maintenance retrospectively Before this maintenance could only claim through the courts. 1961 ordinance also provided for children of predeceased parents to inherit from their grandparents but a wife could not receive share in the inheritance(Ali,parveen,1979,p.31). The Muslim family law over led the concept of Hilala (to marry again the same husband after having an intervening marriage with others person and declared necessary only if a third consecutive divorce of the same people becomes effective(Mumtaz,1987,p.58). The Muslim Family Laws ordinance 1961 was a land mark legislation which was welcomed by the women of Pakistan whole heartedly. They appreciated Ayub Khan the president of Pakistan for this ordinance. However this ordinance was badly criticized by the religions leaders of Pakistan. They opposed it and condemned the law calling it an attempt to tamper with Quran but women condemned their thoughts and they launched movement in support of the Ordiance(MFLO,section.4). Women supported this ordinance and declared it a reform which could save their rights and could empower them to some extent. The enactment of this law was a success for the progressive forces in Pakistan after its birth and women celebrated the event for the first time which they considered a success of their demand and rights. It was a setback for the conservative forces in Pakistan who always condemned any reform which they considered could protect the rights of women even before independence. But the passing of this ordinance symbolized a victory for women rights.

\section{Muslim Personal Law Shariat Application Act 1962}

Muslim personal law (Shariat) application act was extended to the whole of West Pakistan except the tribal areas(MFLO,section.7). This act had an important position because it brought uniformity in the application of Muslim personal law in matters relating to personal life where the parties are Muslims. This Act provided the application of Muslim personal law 
to special property of women. After this law women became legally entitled to inherit property as stated by Muslim law and the next matter was that Muslim law became applicable to family life: In this way 1962 Act tried to focus on Muslim personal law and the courts of Pakistan could reinterpret Muslim laws which were different form the interpretation made by courts in British India.(Patel,1979,p.17).

\section{Family Courts Act 1964}

The Family Courts Act 1964 paved the way for the establishment of courts having exclusive jurisdiction on matrimonial cases. Powers of magistrate first class were given to the judges of the courts. It gave the power to family courts to grant maintenance under section 488 of the $\mathrm{CrPc}$ in addition to their powers as a family court. These courts were located at the district level so that women could approach these courts available in each Tehsil. The advantage was that there was summary trial and maintenance granted could be realized as it was a fine and could be granted through the courts. These courts could play the role of reconciliation at two stages at pre trial stage and after closing of evidence section 12 , of the family courts.(On the path of empowerment, MOWD,p.34).

The Legal Status of Women under The constitution of 1956 and 1962

Both constitutions have recognized the legal status of women as equal under the law because the development of women is seen as the development of society. Under the 1956 constitution Pakistan was declared an Islamic Republic but an advisory role to Ulema was provided. They demanded for the exclusion of women from participation, taking part in the election and a ministry for religious affairs and separate electorates for Muslims were not accepted by the constituent essembly(Syed,1982,p.68).

In 1956 the first constitution was promulgated finally. This constitution recognized men and women equal under the law 1956 constitution accepted the principal of female suffrage for women's reserved seats on the basis of special women's territorial constituencies and the dual voting rights were given to women, for general and reserved seats(Mumtaz,1987,p.56). The constitution under article 14 and 17 accorded safeguards against discriminations. The employment opportunities which were suitable for women, just and human conditions of work which was suitable for them as well as maternity benefits for women employment. In the 1962 constitution all these provisions were added.

1961 ordinance was so strongly opposed by the religious group that to save the ordinance, the 1962 constitution as well as 1973 constitution extended it constitutional protection.

During 1961-1971 an important event was the matter of contesting election of Mohtarma Fatima Jinnah for the head of the state() Fatima Jinnah contested election against General Ayub Khan for the president ship in the limited elections held in 1964. However, Ayub Khan tried to disqualify Fatima Jinnah by saying that in the Muslim country a women cannot become the head of state. However interestingly Ulema agreed on the matter that in crises women can become the head of the state. However she contested elections. Though Fatima Jinnah lost the elections but in this way she provided the first impetus to women participation in the politics of the country(Shaheed,1990,p.4). During 1947-1970s many women got 
prominence in Pakistan's political life and Begum Rana Liaquat Ali Khan was one of them. She set up women National Guard and All Pakistan Women Association and she encouraged women to participate in the politics and to participate in all spheres of national life. Women awareness about their rights and empowerment was due to the women's organizations in the country. Although there were not so much women activists and organizations in the country but however the prominent among them was the Bahbood Association. Anjuman jamhooriyat pasand Khawateen (Democratic Association) Karachi. The Behbood Association was formed in 1967. This organization struggled for the social welfare and to evoke a spirit of self respect among the poor women by giving them earning opportunities. The Anjuman Jamhooriyat Pasand which was setup in Lahore in 1948 was the only political organization for women at that time. This organization worked for the women of the working class. It proposed them to come under their banner and work for their emancipation but for the socialist society(Waddy,1980,p.p.88-100).

\section{Zulfiqar Bhutto and 1973 Constitution}

The post Ayub era, 1969 to 1977 was a very significant and positive era for the Pakistani women. This era was the anti-Ayub agitation era. The first general elections of Pakistan's history mobilized all women at the mass level deepening their consciousness and participation(Shaheed,1990,p.5). Zulfiqar Ali Bhutto's tenure was the progressive one for women. During his period the first women Vice Chancellor was appointed. Begum Rana Liaquat Ali Khan was appointed as the Governer of Sindh Assembly. All the government positions and services including the foreign office services were opened for women. Constitution 1973 promulgated during this period, under which included articles to promote women .Participation and tried to eliminate gender discrimination. This was the major legislation affecting legal rights of women in Pakistan. Regarding fundamental rights, It affirms to eliminate exploitation against women(Weiss,2012p.2). Article 25(1) of the constitution guarantees that "all citizens are equal before the law and are entitled to equal protection of law." Article 25 (2) states that" there shall be no discrimination on the basis of sex" clause 3 of article 25 adds that nothing in this article shall prevent the state from making any special provision for the protection of women and children" Article 27 adds that no citizen, who is qualified for appointment in the service of Pakistan shall be discriminated against any appointment on the grounds only of birth". Article 34 of the constitution states that steps shall be taken to ensure full participation of women in all spheres of national life"

Article 38 (a) states that it is the responsibility of the state to "Secure the well being of the people, irrespective of sex, caste, creed or race, by raising their standard of living". The 1973 constitution provided for women ten reserved seats in the National Assembly.( On The path of empowerment,MoWD,p.135). Prime Minister Zulfiqar Ali Bhutto's civilian rule brought administrative reforms and improved women's legal status as enshrined in the 1973 constitution. By the reserved seats for women in legislature, it was attempted to counter the discrimination(Zia,2010,p.5).

\section{Women Rights Committee 1976}

Prime Minister Zulfikar Ali Bhutto formed Pakistan's Women Rights Committee on 31st 
January 1976. under the Chairmanship of Yahya Bakhtiar who was the Attorney General of Pakistan. The purpose to set up the committee was to formulate proposals for legal reforms to improve the Pakistani women's legal, economic and social condition and to provide them legal remedies to get relief in the matters of maintenance, custody of children etc. The committee was consisted on nine women and four men. They were asked to make proposals to improve status and conditions of women (On The path of empowerment, MoWD, p.35).

The United Nations World Conference on women in 1975 gave a further fillip to the momentum of women rights concerns because a delegation from Pakistan also participated(Zia,2010,p.6). They promised many rights for women like maternity rights and making nurseries for the working women having babies who worked in the public sector. The Dowry and Bridal Gifts Restriction Act was enacted in 1976(Gazette of Pakistan,June1976). Through this act restriction put on the amount or money which was given as bridal gift, dowry by parents and it restricted the expenditures on marriage. This act repealed the West Frontier Province Dowry Act of 1972 and the West Pakistan Dowry Act of 1967. The purpose of this act was to curb the evils of dowry(Patel,2010,p.37). Due to this evil ,parents were facing trouble and hardships to arrange their daughter's marriages. During this period government remained having a soft corner towards the rights of women. Begum Nasrat Bhutto the wife of the Prime Minister Zulfiqar Ali Bhutto set up an independent wing being its head and provincial women's wings was also set up. Through these activities a new process of awareness was unleashed(Mumtaz,1987,p.64). During this era many new women organizations also emerged on the scene as the safeguards of women rights in Pakistan. Women's front was established in 1974-75. This organization was in favor of abrupt change in the economic and social system. They believe that women emancipation can be attained only through radical change. Their slogan was "women and Politics are one."

Another organization "Aurat" was formed in Islamabad in 1976-77. Which started work for the progress of women of low income categories. Another organization Shirkat Gah was established in 1975. The goal of this organization was to encourage women to play full and equal role in society.

\section{General Zia-Ul-Haq Era (1977-1988)}

In July 1977 General Zia-ul-Haq's coupe declared the end of Bhutto era and the Islamization period of Zia started. Zia's Islamaization programme consisted of legal reforms regarding the introduction of an Islamic penal code, educational and economic reforms which would be conforming to Islamic tenets. Zia's legal reforms were of three types (1) Procedural Reforms (2) Criminal Law Reforms (3) Structural Reforms. These three types of reforms placed limitations of women's professional and personal lives(Syed,1995,p.135). As we know Zia assumed power with the promise of holding elections within ninety days. But on 2nd February 1979 Zia declared delay in the elections to follow a heavy mandate by ensuring all laws conformed to Islamic principles in Pakistan. To legitimize his dictatorship he took the support from religion and tried to Islamize the society a pre condition to return democracy. In March 1978 Zia announced that he wanted to Islamize the Pakistan penal code(Mumtaz,1987,p.71). 
Under the criminal law reforms Zia promulgated four ordinances. In February 1979 Hudood Ordinance which called for the revisions of country's criminal law system. The Ordinances of Zina to establish criminal penalties for the crime which were sex related as (rape, kidnapping, adultery, enticement, sodomy, prostitution, attempted rape, conspiracy to engage in prostitution and deceitful marriages(Syed,1999,p.141). The prohibition ordinance put penalties on the use of alcohol and prohibited drugs. The Qazf Ordinance established penalties for the wrongful imputation of Zina and the theft of private property.

The most controversial and heated controversy was the enforcement of Hudood Ordinance. This ordinance repealed the provision of Pakistan penal code on rape. This ordinance made extra marital sex a crime.

This ordinance made no distinction between adultery and rape. This enforcement structure was discriminatory against women. This ordinance made zina as in offence against the state. The most effecting to women at the legal level was the part of zina. It consisted fornication, adultery, rape and prostitution. The two sections are these (1) zina (fornication and adultery) (2) zina bil jabar (rape). This ordinance did not make any distinction between adultery and fornication(Mumtaz,1987,p.6). The ordinance stated two types of penalties depending on the kind of proof available. The penalty hadd as defined a punishment ordained by the Quran and Tazir is a punishment which is other than hadd. To impose hadd it is required a proof for zina and zina biliabr the eyewitness testimony of four male adult Muslims witnesses or a confession of the offender and Tazir is given when the offence is considered proved and did not fulfill the requirements which are necessary for the imposition of had(Gooneskere,,2004,p.166). For an adult married Muslim who commit offence of rape or adultery the hadd punishment is stoning to death while for unmarried men or non Muslim is hundred lashes. The criminal danger which women faced under this law is that the rape charge could be changed into zina against the women themselves.

The previous laws on the subject had provided protection to women from the charge of adultery and excluded them from the punishment but this law negated the protection. This ordinance equated quantum of evidence which were required for the proven of adultery (zina) and rape (zina-bil-jabr). In this way Quranic verses meaning of which to protect the women from the charge of adultery which were impossible to prove this type of charge were extended to apply equally to rape(Zafar,1991,p.38). In this way the rape victim hence to suffer in dangerous and helpless position. Under the procedural reforms the most discussed reform was the law of evidence Zia stated on January 2, 1981 that "In my opinion what is of fundamental impotence is that the law of evidence should be strictly in accordance with the Quran and Sunnah.”(COII,Ordinance Islamic Law of Evidence,1982). This new law established a distinctions between the testimony of men and women.

The women's testimony was equated to one half of the men's testimony. Here again the Quranic provision which gave women an extra advantage by allowing her the testimony of another women were reversed to discriminate against her(Zafar,1991,p.38). The main problem in the hudood ordinance was it demanded same level of proof for the cases of zina bil jabr (rape) and zina (adultery) either the eye witness evidence of the four Muslim adult 
men or the confession of the commission of the offence. The male witness should be truthful and pious persons, on this courts had to be satisfied(Assessment of WPA,2006,p.1).

Under this Hudood ordinance thousands of women went in prisons. Women aged over 70 years and girls 11 years have been imprisoned on the charges of zina. Police reports showed on the offence of zina that over 1500 cases were registered against women each year(HRCP,2006,p.10-11). About 3,399 appeals in zina cases were heard by the Shariat Court between the year 1980-1987 Jahangir\&Jillani,1990).

The violation of human rights due to these so called "Islamic legislations were continuously criticized by the women rights activists and human rights organizations. They challenged the discriminatory laws on every grounds (Assessment of WPA,2006). In these circumstances the women action forum or Khawateen Mahaz-e-Amal established in 1981 by a very small group of women, Who perceived Zia's policies as a grave threat to the rights of women. This organization was set up by an emergency meeting which was called by Shirkat Gah, womens resource center. The women of this forum were mostly from the elite families. They perceived the mostly laws promulgated by Zia regime were discriminatory and would compromise their civil status. These women in Karachi, Lahore and Islamabad collected the groups on collective leadership and formulated policy statements and engaged themselves in political action to safeguard the legal position of women. First of goal of WAF was to mobilize support to the case of Fehmida and Allah Bux as the state. This was the first case which cleared the power of zina ordinance 1979 which made adultery a crime against the state(Syed,1995,p.243). Both Fehmida and Allah Bux were given the respectively sentence of 100 lashes in public and stoning to death in public.

To counter these types of laws women action forum emerged on the scene and started to fight against these laws which were discriminatory towards the women of Pakistan because state interpretations of Islamic laws denied to consider women as equal to men, in the judicial proceedings as the testimony of women in the courts was not considered even equal to that of man(Shafqat,2007,p.241). During the regime of Zia ul Haq, women movements totally changed. The earlier women were working for social welfare of women but in this period their course of action changed. These women began calling themselves feminists.

They started to target the issues of forced veiling of women. Separate universities for women and the exclusion of women from National and international sports competitions(Shafqat,2007,p.243).

Women started protesting against these unfair and discriminatory legislation. WAF and other organizations refused to admit the legislation like Hudood Ordinance and Law of Evidence. This was the dangerous crime that a woman who comes to report the case of rape and is not able to prove that it occurred with her is ultimately in the position of having confession by herself as adultery and in the end is subject to the hadd punishment. The case of Safia Bibi who was 18 years blind girl and a servant in the house of others was raped by her master who was a landlord. She became pregnant due to this rape and gave birth to a baby who died at the time of birth. Her father filed a charge of rape. At the time it was impossible to prove the evidence against the landlord master but Safi Bibi as she became pregnant was found to be 
guilty and sentenced the fifteen lashes. WAF and other organizations put pressure on the Federal Shariat court to revise the ruling of the Session Judge and to dismiss Safia's punishment (Mumtaz,1987,p.103). The Tazir punishment which was the 25 years punishment and thirty lashes was given to so many girls who were considered adults under the Hudood Laws. The time since the enforcement of the Hudood Ordinance the number of women prisoners had been increased. Approximately 40 to 45 percent of the women in jails were accused of zina and were waiting for the trial(Report ofCOIW,1987). The Hudood Ordinance elevates the charge of zina to the crime against state from the crime against an individual. Through it anybody could institute a case of zina against anyone. In this way people could harass other people if they have any rivalries against one another. Hudood Ordinance was being used as tool to exploiting other people mostly women. Ex husbands of women, parents who had grudge about the daughters who marry against their will and consent and by the police who wanted to get money as bribery from the people and as a tool of harassment to get control on other people(Asia watch\&WR project,p.60).

This ordinance was misused not only by the investigating authorities but also by the interpreter of the laws(Jillani,1992,p.72). The Hudood Ordinance was considered as a great violation of the women's human rights because this ordinance gave no protection to the victims of rape because this law failed to establish a difference between zina and rape, a women could be declared accused simply because she became pregnant.

\section{The Law of Evidence 1885}

This law was proposed by the council of Islamic Ideology in April 1982 to repeal the 1872 Evidence Act(Syed,A.1995,p.250). In this law it was declared that the testimony of "two Muslims male witness and in the absence of two male witness by the evidence of one male and two female witnesses. Through this law women were disallowed from testifying in certain cases and in other cases their testimony needed another women's testimony. This was worth nothing the restrictions were upheld only in the cases of economic transactions(Weiss, 2012, p.11). This law undoubtedly gave women and men different legal grounds in Pakistan. This formula was derived from the Quranic verses in which it is stated that "Ye who believe! When ye deal with each other in loan transactions involving future obligations for a fixed period of time reduce them to writing. And get two witnesses out of your own men, and if there are not two men, then a man and two women, such as ye choose, for witnesses, so that if one of them falters the other can reminded her."

It was perceived then that the testimony of women's worth was half that of man when this law was passed in the Majlis-i-Shorra, Women organizations especially Women Action Forum started protesting against it. The Qanoon-e-Shahdat was the brainchild of the council of Islamic ideology(Zafar,1999,p.38).

This Law of Evidence relegates women to the inferior legal position because it consider the testimony of women to only half of the weight of men's testimony. Country wide protests held against this law and the most remarkable of them was when WAF and the Pakistan lawyers association (PAWLA) started a march consisting on 300 women towards the Lahore High Court. Police tried to stopped the demonstration by tear gas and batons due to which 
several women got injured as well as police arrested fifty women(Syed,A,1995,p.53). WAF's protests brought the advancement and it resulted the modification in Law of Evidence and it allowed for a judge's discretion if two men witnesses or one man and two females were not available but it remained intact. When the Law was promulgated it had gone through four drafts. Women again rejected it. They objected this law for four different reasons((Mumtaz,1987,p.109). The first one was that the law stipulates that no financial obligation can be put writing without the presence of man the second one was that the term future obligation is ambiguous which can cover any number of circumstances not relating to debt or loan. They argued that Quranic verse for the witness of another woman was only in the condition of forget. Therefore the testimony of first women has the primary position. The law makes no allowance or the fact that the testimony of an educated women who could read and understand the document is more reliable than the testimony of an uneducated man. Who could not read what he is going to sign(Mumtaz,1987,p.110). In this way the Islamization efforts put adverse effected on the criminal justice system of Pakistan as well as on the women's rights and status in the country.

\section{The Law of Qisas and Diyat during Zia regime}

Zia ul Haq's Islamization process also proposed laws regarding Qisas and Diyat. This law of Qisas (justice) and Diyat (blood money) stated that the life of a woman and non Muslim man was half of worth of the Muslim man(Shaheed,1990,p.19). Although this law was never decreed. Due to the outrage from women's groups with its discriminatory Quranic injunctions interpretations which involve blood money and compensation for physical injury and murdur(Syed,A,1995,p.253). This law offered compensation in crimes involving bodily injury. This law proposed that the blood money for a man should be $30.60 \mathrm{Kg}$ of silver, and half justified this proposal by stating that a men who is the money earner in the family must be compensated more(PCSW, annual report,p.143).

WAF took strong action against this law which was based not on the Quranic injunctions but on the several zaif (weak) hadiths. This law of Qisas and Diyat was postponed many times. It was submitted to various committees and sub committees but it was never passed.

Zia's government also introduced the Islamization Programme which produced a shift in the uneasy balance women's rights and religion in Pakistani politics. He introduced benches at the high court level organized and centralized as the Federal Shariat courts. The objective of these courts which were set up in 1980s was to review all laws for the assurance that no law was repugnant to the Quran or the Sunnah. Their task was also to hear certain criminal matter including Hudood cases. In 1983 the Ansari Commission was set up to give proposals through which Pakistani government could make laws in accordance to the Quran and Sunnah. The Ansari commission under the chairmanship of Muhammad Zafar Ansari consisting of nineteen members was given the task to prepare report in three weeks. The report stated that the head of the state should be Muslim male the commission also proposed that the members of the Majlis-e-Shoora would be more than the age of fifty and these women should have the permission of their husbands, if they are alive, to enter in politics(HRW,1999,p.23). The women organizations showed their strong reservations about 
the provision in which the women could not become the head of the state. They said that commission has given unislamic and discriminatory proposals.

This commission also gave proposal for the establishment of separate university for women but this was opposed by the women. In 1985 when Zia announced the political frame work for the Islamic system in Pakistan. He raised the number of reserved seats for women from ten to twenty. He ignored those proposals about the restrictions in election and appealed to women to come and vote in the elections.

In 1986 a legislation with implications on women come with the passage of 9th amendment to the constitution. This amendment stated that all the laws would be according to the Quran and Sunnah: it put family laws in the jurisdiction of Shariat courts which were established by Zia(Mumtaz,1987,p.118). This amendment put the 1961 ordinance in target to be repealed. During this time the Shariat bill was also passed. The women action forum and other women organizations opposed the bill on the grounds that the Shariat Bill will negate many of the rights which women have got after a long struggle. It is evident that all policies of Zia regime were against women rights subsequently the laws passed during this regime curtailed women rights and put them on inferior position in society. It adversely effected women participation in social arena The postings of females in foreign offices were cancelled. A dress code for women was also introduced, women at colleges, universities were asked to veil themselves properly. The participation of women in politics was also discouraged.

In 1987 Zia-ul-Haq was died in a plane crash near Bahawalpur and a decade of his regime came to an end.

\section{The Era of Benazir Bhutto and Nawaz Sharif (1988-1999)}

This was the period of uneasy democratic interregnum and was dominated by political confrontations. In this period political parties struggled to make their position strong to define a culture of democratic relations. In 1988 elections Benazir Bhutto assumed the office of Prime Minister with the expectation of Pakistani People that she would be a savior being a symbol of progress and victory for women and society. Benazir Bhutto was the daughter of Zulfikar Ai Bhutto, so the women were expecting such policies which will bring radical changes to change their status and removal of discriminatory laws and repealing of controversial Hudood Laws(Syed,A,1995,p.254). But during her two terms of government she did not repeal a single law which Zia promulgated(HRW,1999,p.24). However some measures were taken for the advancement of women but little was done to the rights of women. Women police stations and First women bank were set up during this period. Women judges were appointed and study centers for women in universities were established. The twenty year plan for Beijing plan of action developed. In 1990 Pakistan a state party to the United Nations, signed the 1993 Vienna declaration recognizing women rights as human rights. And The Forward Looking Strategies for the Advancement of Women (FLSAW) in Nairobi(Zia,A,2010,p.6). In March 1996 Pakistan government ratified the convention on the elimination of all forms of discrimination against women (CEDAW). In 1997 the commission of inquiry for women (COIW) identified the laws which were discriminatory to women and presented recommendations in this regard. In March 1996 Pakistan government ratified the 
convention on the elimination of all forms of discrimination against women(Weiss,2012,p.5). In 1998 the government of Pakistan established a National plan of action (NPA) for women. It is a document which provide guideline and outlines strategic actions for the social, economic and political empowerment of women in Pakistan.

\section{The Law of Qisas and Diyat 1990}

The Qisas and Diyat Law Ordinance was first added to the legal system of the country in 1990(PNR of Beijing+10,MOWD,p.65). It was an Ordinance introduced in 1990 to Islamize the criminal justice system of Pakistan. It was promulgated several times but it was passed as an act in 1997 under the Nawaz Sharif government. This Act replaced many sections of the Pakistan Penal Code (PPC) which were related to murder, man slaughter, physical injury etc. The Section 300 of 1990 law stated that when with the intension of causing death or with the intention of causing bodily injury to a person, doing an act which in the ordinary course of native is likely to cause death, or with the knowledge that his act is so imminently dangerous that it must in all probability cause death then it is said to be qatl-i-amd. (intentional murder).

The murder punishment in the section 302 of the Pakistan Penal code states, Whoever commits Qatl-i-amd shall be punished with death as qisas. The definition of Qisas is in section 299 as punishment by causing similar hurt at the same part of the body of the convict as he has caused to the victim as by causing his death if he has committed Qatl-i-amd in exercise of the rights of the victim or the wali.

The law of Qisas and Diyat altered the concept of crimes against the state to giving the victim or the heirs of the victim the right to prosecute the case Goonesekere,2004,p.151). In this way if a domestic violence case comes before a criminal court, it is punished with Qisas (retribution) or Diyat (Compensation). It is done for the interest of the victim or for his or her heirs so if the victim or heir of the victims waive qisas then the offender is given the tazir or discretionary punishments like imprisonment (Goonesekere,2004,p.152).In these conditions judges of the criminal courts have the power to decide the extent of punishment and to decide whether to punish the offender at all(HRC,1999,p.41). The Qisas and Diyat law have converted the serious crimes like murder into crimes against the individual rather than state.

In this way law has given the right of forgiveness to individual even in serious crimes like murder. So in patriarchal countries like Pakistan, the powerful section of society(men) will put pressure on the weaker section of society (women). Qisas and Diyat law has privatized the crimes especially the crimes of interfamily violence. In such cases ultimately family put pressure on the women for waiving Qisas. This ordinance made criminal offence a private matter. The concept of wali a person who could claim Qisas always become men it appears from the language of the law that wali will be always a man. Although the law refers to daughters as wali but in the male dominating society wali would be always a man. This law had put extremely damaging implications for women. In the case of women murdered by men of their own family, the family will hesitate to prosecute the case against their own family member. Similarly this law provides that the death penalty cannot be imposed if the wali is the direct descendent of the offender. So in the cases where a man murders his wife and they have a child, he cannot be sentenced to death because the wali of his wife is his 
child who is the direct descendant of the man (Pakistan Penal Code, sec.34).

In the same way Diyat in these types of cases entailing compensation taking from a father to his child is an absurd thing or mockery (Amnesty International,Sep,1999,p.45). The courts however can impose tazir punishments regarding to the facts and circumstances of the these types of laws which are very much discriminatory towards women. A large number of men killed their women because they are assured that they would not be given death sentence and will only bear the imprisonment for some years.

During the tenure of both democratic governments, no sufficient efforts were made to improve the legal status of women. Benazir Bhutto came to power with the promise to repeal the Hudood Ordinance, a discriminatory law which was promulgated under the military regime of Zia ul Haq. It remained the part of her election campaign but after getting the office of Prime Minister she did not enact even a single law to repeal the discriminatory laws(Human Rights Watch,1999).

Benazir Bhutto was the first woman Muslim leader in the South Asia who reached to the power of the head of the state. It raised the moral of Pakistani women and with the ratification of the (CEDAW) in 1996 it was hoped that the status of Pakistani women would be better after following the articles of (CEDAW). In 1996 Benazir government announced to take some measures to make the Pakistani women plight better. The Federal cabinet announced in 1996 that the death penalty for women would be abolished(Weiss,2012,p.5). They argued that it is rare to see that women are seen indulging in serious crimes like terrorism and murders. Benazir Bhutto also ordered to release women prisoners under the Hudood Laws.

Nawaz Sharif's two governments took actions to indicate a political strategy of Islamisation. In his first period (1990-1993). He promised to adopt the Islamic laws as the supreme law of Pakistan. He enacted the Qisas and Diyat ordinance in 1997. He introduced fifteenth amendment to the constitution with the aim to repeal all existing laws according to the Islamic one. His proposal was approved by the lower house but it had to face opposition from the women groups.

\section{Commission on the Status of Women}

In 1994 The Senate of Pakistan decided to establish a commission to review the laws of the country which were discriminatory towards women or were creating hurdles in their way to become equal citizens of Pakistan. The house recommended that the commission should be consisted on Ulemas, jurists and representatives of women with a judge of the supreme court of Pakistan to review the existing laws and legal status of women in Pakistan (Ayesha, 2005, p.105). The major purpose of this commission was to give recommendations regarding legislation concerning or affecting women. It deals with all legal issues including family laws, economic rights, criminal laws, including Hudood Ordinance (1979) Law of Evidence 1984 and violence against women. The report of the commission was made public in 1997.The report contained comprehensive recommendations regarding legal reforms and were appreciated by women. Its report came to public in 1997. It reviewed constitutional 
provisions and then presented modifications. This commission also condemned the existing situation of Pakistani women. It states that "There is a wide spread misconception about the place Islam accords to women". It is believed that Islam relegates women to an inferior status, it confines them inside the four walls of their house and it restrains them from taking up employment outside their homes or running their own business. This is wholly contrary to fact(MOWD,Peport). The commission suggested that all laws which are not according to the real sense of Islamic injunctions should be abolished so that the real and fair concept of Islam should brought before the world. Pakistan government in 1998 launched a National plan of action for women.

\section{National Plan of Action and Ministry of Women Development}

National plan of action was initiated by the Ministry of women development (MOWD). This Plan of action for women established a set of priority actions formulated to help in achieving the agendas for their empowerment in Pakistan (MOWD,Reports of COIW,1997). In 1996 a ministry was set up by the federal government by strengthening the women's division in the cabinet secretariat which was established in 1979 as the follow up to the women rights committee recommendations. This division was upgraded in 1989 as a monastery for women development (Gender Reform Action Plan) In its beginning this ministry had only a marginal presence in the provinces that is why it was not able to make affective changes. In 1996, social welfare and special education were also merged in it and the name of ministry became Ministry of women development, special welfare and special education. Although all these steps were taken but no legal reform enacted towards the protection of rights and empowerment of women.

\section{Musharraf Period towards Empowerment}

Musharraf came on the political scene of Pakistan through a coup d'état in October 1999. He adopted the effective policy approach towards the empowerment of women. Musharraf had an enlightened moderation theme. Under this theme Musharraf government inducted seven women ministers in the federal and provincial cabinets. These ministers held the charge of key ministeries like department of law, women development, education social welfare, population welfare and special education. Every military government tried to legitimize its position by making policies like local bodies elections and by the programme of islamaization or by the promotion in the status of the weaker sex of the society. Pakistani women got remarkable law, Muslim Family Laws Ordinance in the period of military ruler M. Ayub Khan but in 1979 another military ruler General Zia ul Haq curtailed the women rights and position in the society by the promulgation of Hudood Ordinance 1997, Law of Evidence 1985. Luckily Musharraf government took steps to heal the grievances of women in Pakistan. The government of Musharraf was committed in improving the status of women in country. His government took a number of steps and measures to release women from the reasons which held them back and to speed up their progress.

\section{National Commission on the Status of Women}

In July, 2000 government set up a National Commission on the status for women. 
Commission was set up with several objectives to promote the status of women but the main objective was to renew all laws, rules and regulations which were affecting the status, position and rights of women. The second main objective was to suggest amendments and recommendations and new laws which could be effective to eliminate the discrimination against women in the society and to promote and safeguard the interests and rights of women. This commission was set up by the presidential ordinance(NCSW,2000). It was defined in the ordinance that the majority of members in this commission would be women and one member from each province shall also be included. Azad Jammu and Kashmir, Northern Areas and at least one member from the minorities. The Chairperson would be appointed by federal government. It was mentioned that the commission will present annual reports to the President and lay them before Majlis-e-Shoora (Parliament). The criteria was set up for the members as the persons who were committed to the cause of women, had status and integrity in the society, with substantial experience in law or legislations and had the knowledge of legal problems of women. In this way it was obvious that the government was very much concerned towards strengthening the legal status of women Musharraf appointed a women activist as the minister of state for education (The Gazette of Pakistan,July,17,2000).He also included Omar Asgher Khan a famous social activist in his cabinet. All these activities were due to the progressive attitude of Musharraf which led to effective policy for the empowerment of women. During the Musharraf period the incident of 11th September 2001 occurred which totally changed the whole scenario of the world. Pakistan now needed to adopt policies which would make it prominent in the world.

The first National Policy for development and empowerment of women was formulated on March 2002 by the President of Pakistan(Weiss,2012,p.5). This policy was the intent of the government which formulated policy measures for social, political and economic empowerment. The process started to amend the laws, first of all in April 2000, General Musharraf gave consent for the changing in Blasphemy Laws under which a person could be arrested only on the complaint of any one which could be resulted in death sentence but under the amendment it was proposed that to arrest anybody on the complaint, should not be effected until the investigation by the district administration. Although, He have to give up amendments due to the opposition from religions parties his address to Ulema and religious scholars that Islam teaches us tolerance not hatred, universal brotherhood and not enmity, peace and not violence, progress and not bigotry, I have great respect for Ulema and expect them to come forth and present Islam in its true light. I urge them to curb elements which are exploiting religion for vested interest and bring bad name to our faith(Singh,2008,p.38). Women in Pakistan and their rights which Islam had bestowed them were also had been suffering in earlier periods due to these extremist religious portion of the society which were interpreting Islam according to their own vision. In the Musharraf period women of Pakistan were also being radicalized expecting that Musharraf will also bring amendments towards the discriminatory laws which were curtailing the path of women progress.

General Parvez Musharraf also tried to rehabilitate better image of Pakistan, which was badly tarnished after $9 / 11$ incident in the comity of nations. A series of legal reforms were introduced during his period at Amendment in citizenship act of 1951. Human trafficking 
ordinance 2000 under this law of citizenship act which was amended replacing the word "father" with "parent" purpose was to eliminate the gender based discrimination in nationality by descent section 4 replaced. The words his and father replaced by his or her and either person respectively

The ministry of interior took action for the enactment of a new ordinance, prevention and control of human trafficking in 2002 to prohibit the illegal smuggling of women and child girls for forced labor and prostitution (Singh, 2008, p.238). General Parvez Musharraf approved devolution plan 2001 which proved a watershed for the political empowerment of women. The local government ordinance 2001 provided 33\% representation of women in all tiers of local government through this process a vast majority of women got representation in union councils, town councils, tehsil councils and district councils.

In Punjab Province women's seats were 20718 in the Union Council from which 20007 women elected. In Sindh 6498 seats women elected on 5878. In NWFP now (KPK) 5742 seats from which 3963 women elected. In Balochistan 3108 seats and women elected 2374. In 2002 elections women legislative representation remained as on the total seats of 1170 the percentage of women elected against Quota was 19.9 percent categorically in National Assembly total of 342 seats women were 74 as $21.6 \%$. In Senate seats of 100 women seats were 18 as $18.0 \%$ Punnjab Assembly 37 seats in which 73 as $19.7 \%$ were women in Sindh assembly 168 seats 33 as $19.6 \%$ were women in NWFP 124 seats women seats were 23 as $18.5 \%$ percent were women (Year Book, MOWD, 2003-2004,p.29). These women members in through nominal representation but result in great voicing for initiating legislation on all types of issues which were confronting the women rights in Pakistan. Future programmes were started with the fund of United National development Programme with the aim as an effort to develop the capacity of over 36,000 newly elected women councilors at district, tehsil and union council levels with the name of women's Political Participation Project (W3P) (YearBook,MOWD,2003-2004,p.31). General Parvez Musharraf while addressing a convention on Human Rights and Human Dignity held in April, 2000 condemned the honor killing and called it a murder and directed all concerned organizations to treat it as such before this. On 1st July 2000 Juvenile justice ordinance promulgated. Special courts for children were established under this law the death penalty was abolished for the persons who were under the age of eighteen. Further steps towards the safeguard of women rights were taken by assigning the optional protocol to the convention on the rights of the child on sales of children, child prostitution, child pornography on 26, September 2001. General Parvez Musharraf government emphasized more on elimination of violence against women in the society.

Government of Pevez Musharraf was very much conscious towards its responsibilities under the Universal Declaration of Human Rights and Convention on the Elimination of all forms of Discrimination against Women (CEDAW) which has been ratified by Pakistan government since 1996 and Beijing platform for action. Violence in Pakistan took many forms from Physical abuse to sexual, emotional, psychological and economic abuse. The customs and tradition of the society and harmful practices in it all are the form of violence against women, which restrict women to take part in decision making and play their role as an independent 
citizen of the society. So what is violence? the society and its citizens should know the term violence, its kinds and effects on the women. There are some definitions from which we can understand what violence is. According to LizKelly, violence against women involves behavior that is violent uses physical force or threat and is intimidating, coercive damaging to women. It includes physical, sexual, verbal or sexual acts that are experienced by a women or girl at the time later as a threat, invasion or assault and acts that have the effect of hurting or degrading her and taking away her ability to control connection with another individual(Levy,2008,p.3). UNO's 1993 declaration on the elimination of violence against women defines violence against women as "any act of gender based violence that results in or is likely to result in physical, sexual or psychological harm or suffering to women, including threats of such acts, coercion or arbitrary deprivation of liberty, whether occurring in public or private life."184 These definitions cover most common types of violence that women face in homes in public places and at the workplaces.

Violence is the most pervasive yet under recognized human rights violation. In all over the world violence has far reaching negative effects on women and their lives. Violence against women was acknowledged as a violation of human rights firstly in the fundamental human rights at the 1993 world Conference on Human rights held in Vienna(Levy,2008,p.4). The concept is rooted in the belief that women are the property of men. Violence is an action or an attitude that causes bodily or mental injury and dehumanizes a person(Gooneskere,2004,p.148). Women rights violation is a human rights violation of her body and her rights as a person. The Vienna declaration and programme of action declared women's rights to be human rights.

Pakistani women is weakened by the social norms of the society and violence against women is rooted in the social relations of patriarchy, and it is based on a system of male domination and female subordination. Women in Pakistan suffer different kinds of violence at domestic level in the society and at work places.

Domestic Violence is a private matter in Pakistan. Pakistani society is based on patriarchal culture, so domestic violence is performed by hitting, slapping and kicking. Police, society and law enforcing agencies consider it a private matter and hesitate to take action against it. It remains unnoticed until it takes sever form of murder. Domestic violence is conducted in different forms as physical assaults and techniques are used to control the other. To undermine a person's self-esteem psychological abuse is the main technique. United Nations report states that "wife abuse is a common and pervasive problem and that men from practically all countries, cultures, classes and income groups indulge in this(Pickup\&Suzzonne,2001,50). In Pakistan violence against women is a general feature of life "a way of life" (UN report,p.1971980). Although domestic violence especially spousal violence is viewed as a private, internal family matter and that's why not to be interfered with. However these violence have serious implications for the women victims. The cases of human torture and cruelty are growing rapidly but majority of these cases goes unaddressed and unnoticed. Violence at domestic level by the husband on wife is a very common feature in Pakistan. There are many examples of this practice and women have to bear it because of structural barriers which society has built for them. Men want to control women by 
employing different means.

These types of violence against women which have lethal impacts on women's dignity and security. Many harmful customary practices which keep women subjugated and prevent them to their self realization and access to their rights under law. Although the laws and law enforcing agencies, The commission on the status of women are struggling hard to counter and prohibit all these types of harmful practices which are detrimental to women's rights and status.

Women organizations and human activists struggled hard to convince the government and law enforcing agencies to take the notice of the increase in rape cases, sexual and physical abuse and exploitation of women. Government and its established commissions have taken eminent steps to repeal the laws which are discriminatory towards women.

The government of General Pervez Musharraf took many steps, amongst them is the formulation of National Policy for development and empowerment of women. The aim of the policy was to remove the inequalities and imbalances in all sectors of women development (Gooneskere,p.194). This policy was a statement of the intent of government to take its measures for the development and empowerment of women. Towards the violence against women the policy took measures to address those issues by adopting a zero tolerance policy towards violence against women, to declare honor killing as a murder, to introduce laws and reforms on domestic violence ensuring implementation and enforcement of existing rights and removing discrimination by legal reforms. In this regard policy was formulated that the ministry of law, justice, human rights and Parliamentary affairs, The Pakistan law commission, and The National Commission on the status of women will review all laws and make new laws wherever it needed. Earlier there was no law or forum to give protection to the victims of domestic violence. The women were demanding to seeking redress and to amend the law. General Pervaiz Musharraf amended the family court act women were demanding that the family courts should give the power to deal with cases of domestic violence(National Policy,2002). Musharraf brought amendments in the schedule of section 5 (jurisdiction of the family courts) a subsection added which increased the jurisdiction of the family courts to offences of domestic law(The Gazette of Pakistan,1st,Oct,2002). The power was given to the family court judges of a judicial magistrate first class to punish offences under the penal code for the acts of causing hurt, wrongful confinement perpetrated by spouse. It was also added that the gestures, words and acts showing insult to the modesty of women are also punishable by a family court. This amendment gave the right to family courts to give punishment to husbands who beat their wives and considered it a family or private matter. Now the courts could award punishment or an offence regardless of the relationship of husband and wife. Several policies were adopted to make the status of women better. The most significant action which was taken in this period was the implementation of criminal law (Amendment Act 2004).

\section{The Criminal Law (Amendment Act 2004)}

The Criminal law Amendment Act 2004 was based on the concept of justice in Islam and Qisas and Diyat to deal with the honor crimes(The Gazette of Pakistan,1st ,Oct,2002). This 
law was based on the recommendations of National Commission on the status of women (NCSW) which was established in 2002 by the Presidential ordinance. The main objective of this commission was to revisit the laws and policies and give recommendations to create new laws for the protection and safeguard of women. The commission observed, that crime on the name of honor is prevalent throughout the country. In under developed areas of Pakistan, honor crimes and discriminatory laws were affecting women badly. Pakistan's interior ministry records that more than 40100 honor killings between 2000 to 2004 . According to the nongovernmental organizations there were 600 honor killings only in 2004(NCSW,impact assessment,2004,p.3). Issues which are related to violence against women were intimately bound up with the legal system the Hudood Ordinance 1979 which set up differentiation in the legal statuses of both genders(HRC,2004) The second major issue was the family honor which is considered to be violated when there found any suspicion about the illicit relationship of women with men, to whom she is not married. Women in Pakistan are murdered only on the suspicion of this relation in some cases(Akbar,1992).

In Pakistan hundreds of women are killed on the name of honor every year with the allegation of such as adultery, premarital sex, marrying without the permission of the parents or having been raped. In Pakistan rape is considered a shameful offence for family and mostly in these cases the family members or Jirga decided to murder that girl who has been raped because she has become the cause of shame for the family. According to Nilofer Bakhtiar, The adviser to the Prime Minister on women development she stated that there were 913 women were killed in honor related crimes during the 2003 year with the average of 638 cases in Sindh 463 in Punjab, 120 in the NWFP and 40 in Balochistan(Iqbal,1990,p.5). So there was an urgent need to repeal the laws on honor crime. Gernal Pervez Musharraf had already declared at the Convention on Human Rights in 2000 that "The government of Pakistan vigorously condemns the practice of so called honor killings." Such actions do not find any place in our religion or law. Killing in the name of honor is a murder, and it will be treated as such. In April 1999 when a girl named Samia Sarwar was killed on the blame of disgracing her family because she wanted divorce from her abusive husband who was her cousin. She was shot dead in front of the office of her lawyer Hina Jilani(MOI\&MLJ,2000). This offence was highlighted on the media at national and international level, Women organizations, human rights watch, human rights commission of Pakistan all condemned this murder and demanded for law reform. They collaborated with the governmental institutions like National Commission On the Status of Women (NCSW) which arranged meetings in all the capitals of provinces with legal experts, human rights activists and religious scholars to ponder upon the laws regarding honor crimes. These organizations with the deep consultations drafted a legislative bill to counter honor killing(Welchman\&Hosain,2005,p,101). This draft bill recommended to repeal the PPC and CrPC by adding a definition of "honor killing".

The Honor killing is defined as follows, "Qatl-e- amd in the name of honor shall mean and include qatl on grounds or pretext of Karo Kari, Siya Kari or any other similar custom”. The National Assembly of Pakistan passed this bill in January 2005 with the name of criminal law Amendment Act 2004. The amendments with the sections relating particularly to honor killings are in section 299 under which sated that offence committed in the name or the 
pretext of honor" means an offence committed in the name or on the pretext of Karo Kari or Siya Kari or similar other customs or practices.(Gazette of Pakistan, 2005).

Under amended section the definition of the murder was changed in the Pakistan Penal Code. The murders committed in the name of honor had been declared simple murders.

Under amended section 302. Act XLV of 1860 "Provided that nothing in their clause shall apply to the offence of qatl-e-amd if committed in the name or on the pretext of honor and the same shall fall within the ambit. According to this amendment the maximum imprisonment was of 25 years and not less than 10 years for the offence(Gazette of Pakistan,2005). Under the section 310 and 331 of the Pakistan Penal Code the girls given in the marriages as badl-e-Sulha was prohibited and the punishment of offence under these sections declared 14 years imprisonment and the minimum punishment would not be less than seven years. Section 324 amendment seeks to include the hurting of a victim as an honor crime. In the honor related hurt cases, the punishment could be awarded minimum of $1 / 3 \mathrm{rd}$ of stipulated penal code. For blasphemy cases investigation has to be conducted by a superintendent of police and no officer below this rank would be eligible to handle these types of cases as well as the amendment to section $56 \mathrm{~B}$ explained that only superintendent of police will investigate the cases of woman accused of the offence of adultery. According to amendment ,the punishment of honor killing would be life imprisonment or death. The definition of wali (legal heir) had changed in this way wali will not include the accused person in the crimes which would be committed in the name or pretext of honour. The provincial government will not have the powers to suspend the punishment which had been given in the cases of honour).

This law was drafted in 2004 but enforced in 2005. This law was popularly called as the honor killing law. This law however did not really address the issue of waiver or compounding under which the perpetrators were given the advantage of seeking forgiveness from the heir of the victim(Weisse,2012,p.3). Which was the biggest flaw in the Qisas and Diyat law. Under which the victim had the opportunity to forgive the murderer by taking compensation Diyat as blood money or could forgive the murder in the name of God.

Honor killings are the crimes which are committed by close relations mostly by father, son, brother or husband and by the factor that the family member may forgive the offender, who is also the member of the victims family or by accepting Diyat (blood money). They could be prescribed to accept the Diyat. The criminal law amendment bill did not address the law of waiving and compounding. In this way the murderer will be escaped from punishment (ACHRrepot,28,Oct,2004).However some improvement in the effective implementation could be helpful for the Amendment Act, 2004.

\section{Conclusion}

Women who were forced to live in the four walls of houses had started their struggle against this discriminatory and patriarchal mindset even before independence in British colonial India.Many social and legal reforms were introduced to improve the status of women The step towards women empowerment and to safeguard their rights had been taken seriously 
by the women and human rights activists. After independence this struggle remained active and resulted in the form of MFLO1961 but after the promulgation of Hudood Ordinance this struggle emerged in the form of WAF which demonstrated against these discriminatory laws and demanded to repeal it.New laws are being introduced However, much work is needed to be done for the rights for women which were set backed by the General Zia-ul-Haq regime.Now governments are taking several steps to form the gender related policies to tackle. But there is more need of amendment in laws for the empowerment of women and for safeguarding women rights. Much steps has taken to improve the status of women as declared honor killing a murder, which was a remarkable step, but there is also a need of devising a mechanism for implementation of these laws.

\section{BIBLIOGRAPHY}

- Ali, Parveen. Shoukat.(1979). Legal Status of Women in The Third World. Lahore: Aziz Publishers.

- Ali, Parveen, Shoukat,(1980).Human Rights in Islam. Lahore: Aziz Publishers.

- Ali, Azra. .Asghar.(2000).The Emergence of Feminism Among Indian Muslim Women: 1920-1947. New York: Oxford University Press.

- Ali, Shaheen. Sardar.(1995).A Comparative Study of The United Nations Convention on The Elimination of all Forms of Discrimination Against Women, Islamic Laws and the Laws of Pakistan. Peshawar: .Asia Watch and the Women's Rights project.

- Amnesty International.( September 1999). Violence against women in the name of honour.

- Asia Watch \&The Women's Rights Project.(1992).Double Jeopardy: Police Abuse of Women in Pakistan, New York: Human Rights Watch.

- Basu, Aparva \& Pay, Bharati. (1990). Women's Struggle: A History of the all India Women's Conference. (1927-1990). New Delhi: Mahohar Press.

- Council of Islamic Ideology, Draft Ordinance, Islamic Law of Evidence (1982). Islamabad: Printing Corporations of Pakistan.

- Human Rights Watch.(1999). Custom or Crime? Violence against Women in Pakistan. New York: Oxford University Press.

- Davies, Miranda.(1994).Women \& Violence. Atlantic Highlands, N.J: Zed Books.

- Forbes, Geraldine.(1998). The New Cambridge History of India: Women in Modern India. U.K: Cambridge University Press.

- Goonesekere, Savitri. (2004). Violence, Law and Women's Rights in South Asia. New Delhi: Sage Publications.

- Gazette of Pakistan Extraordinary dated 20 June. 1956 Report of the Commission on 
Marriage and Family Laws

-Gazette of Pakistan, Extraordinary, Criminal Law (Amendment Act) 2010.

-Gazette of Pakistan Extraordinary, part, 2nd December, 2006. Protection of Women (Criminal Laws Amendment)Act.

-Gazette of Pakistan Extraordinary, June 1976.

-Gazette of Pakistan,. June 20, 1956.

-Hassan, Yasmeen. (1995).The Heaven Becomes Hell: A Study of Domestic Violence in Pakistan .Lahore: Shirkat Gah.

-Hellum, A\& Aasen, H.(2013).Women's Human Rights: CEDAW in International, Regional and National Law. New York: Cambridge University Press.

-Hussain, Sabiha. (2006). Muslim Women's Rights Discourse in the Pre-independence Period. New Delhi: Centre for Women's Development Studies.www.gwds.ac.in/sabihaoccasionelpaper.pdf.

-Jalal, Ayesha.(1991).The Convenience of Subscription: Women and the State in Pakistan Philadelphia: Temple University press.

-Jahangir, A \&Jilani, H. (1990). Divine sections? A research study of the Hudood Ordinance and their effects on the disadvantaged section of Pakistan society. Lahore: Rhotas Books.

-Jalalzai, Farida and Krook.L. Mona. (2010). Beyond Hillary and Benazir: Women's Political Leadership Worldwide. http://www.sagepub.co.uk/journalspermission.nav.

- Jillani, Hina. (1992). Whose Laws? Human Rights and Violence Against Women in Pakistan. New York: Oxford University press.

-Khan, Rabia.(2009)Situational Analysis and Mapping of Women's Rights.submitted to CIDA,Pakistan programme.

-Khan, Tahira. Shahid. (1999).Chained to Customs" The Review.

-Lateef, Shahida. (1990). Muslim Women in India, Political \& Private Realities: 1890s-1980s. London: Zed Books Ltd.

-Law and Justice Commission of Pakistan Releasing the Female Accused on Bail.www.commonlii.org/other/pkjc/reports/48.html.

-Madani, Aiysha. (2005). Contemporary Thoughts in Women Rights, Islamabad: Poorab Academy.

-Mahmood, Tahir. (1995). Statutory Laws relating to Muslims in India. New Delhi, Institute of Objective Studies. 
-Mirza, Anis. (1977). Women's Role in Pakistan Movement and the Formative Years, Lahore: Van guard Books.

-Mirza, Naeem.(2011).Seven Pro-Women Laws in Seven Years, Legislative watch, Issue No,38.p.1.www.af.org.pk/Newsletter/ul2011/NLEEnglish.38.pdf.

-Moreno, C. Garcia \& Rossler, A. Riecher. (2013).Violence against Women and Mental Health. Switzerland, Karger Publishers.

-Muslim Family Laws Ordinance, Section 4 \& 7.

-Mumtaz, Khawar \& Shaheed, Fareeda. (1987). Women of Pakistan: Two Steps Forward, One Step Back. Lahore: Vanguard Books.

-Naheed, Kishwar. (2008). Women: Myth and Realities Lahore: Sang-e-Meal Publishers.

-National Committee for British Century(1976). Celebrations of Quaid-e-Azam Muhammad Ali Jinnah, Quaid-e-Azam and Muslim Women. Karachi: National Book Foundation.

-National Plan of Action.(1998).Ministry of Women Development Social Welfare And Special Education.

-Otte,M.Jan.(2010).Sharia Incorporated:A Comparative Overview of the Legal System of Twelve Muslim Countries in Past and Present. Lieden University Press

-On The Path of Women's Empowerment: A Synthesis of Report of Commissions/Committee on the Status of Women, 24 December, 2003. Government of Pakistan, Ministry of Women Development, Social Welfare and Special Education, Islamabad.

-Patel, Rashida. (1979). Women and Law in Pakistan. Karachi: Faiza Publishers.

-Patel, Rashida. (2010) Gender Equality and Women's Empowerment in Pakistan. Karachi: Oxford University Press.

-Pickup,Francine.(2001).Ending Violence Against Women:A Challenge for Development and Humanitarian Work. Oxfam Publishers.

-Pakistan Commission on the Status of Women. Pakistan National Report Beijing +10 Ministry of Women Development Islamabad.

-Pakistan Commission on the Status of Women, The Report of the Pakistan Commission, Quoted in Pakistan in Islamabad. Pakistan. 1984.

-Salahuddin, Ambreen. (2005). Feminism in Modern Urdu Poetesses. Lahore: Tayyab Iqbal Printers.

-Sarajuddin, Muhammad. Alamgir. (2011).Muslim Family Law, Secular Courts and Muslim Women of South Asia: A Study In Judicial Activism. New York: Oxford 
University Press.

- Sarajuddin, Muhammad. Alamgir. (2001). Sharia Law and Society: Tradition and Change in South Asia.

- Sen, Samita. (2000). Towards a Feminist Politics? The Indian Women's Movement in Historical Perspective. World Bank Policy Research Report.

- Shafqat, Saeed. (2007). New perspectives on Pakistan: Vision for the Future. New York: Oxford University Press.

- Shaheed, Farida.(1990).Pakistan's Women: An Analytical Description. Lahore: SANJH Publishers.

- Shahidullah, M. Shahid. (2012).Comparative Criminal Justice Systems: Global and Local Perspective. USA: Cathleen Sether.

- Singh, R.S.N. (2008).The Military Factor in Pakistan. New Delhi: Lancer Publishers.

- Syed, Anwar. (1982). Pakistan. Islam, Politics and National Solidarity. Green Wood Publishers.

- Syed, Aslam, Muhammad.(1995). Islam and Democracy in Pakistan. Islamabad: Crystal Printers.

- Sehgal, M. Ikram.(2006).Defence journal,volume9,issue12_volume10, issue12.

- ShirkatGah.(2004). "Why The Hudood Ordinance must be Repealed" Lahore: Women's Resource Center.

- Shaheed, Farida. (1994). Women in Politics: Participation and Representation in Pakistan. Lahore: Shirkat Gah.

The (MFLO) 1968. Gazette of Pakistan dated 2nd March 1961.

- The Report of the Commission on Inquiry of Women. August 1997

- Thomsen, Natasha.(2010).Women's Rights: Global Issues. New York: Viva Book's Publication.

- UN CEDAW Verdict. (2007). (Concluding Comments) on Pakistan's Combined Initial, Second and Third Periodic Report.

- United Nations Convention on The Elimination Of All Forms of Discriminations against Women.

- U N Development Programme. (2009).Facets of Violence Against Women Gender Justice and Protection Project.

- United Nations Entity for Gender Equality and Empowerment of Women.(7feb2012).www.unwomen.org/en/news/stories/2012/2/historic. 
- Waddy, Chris. (1980). Women in Muslim History. London: Longman group Ltd.

- Weiss, Anita, M. (2012). Moving Forward with the Legal Empowerment of Women in Pakistan. United States Institute of Peace .www.usip.org

- Welchman, Lynn\& Hossain Sara. (2005). 'Honour': Crimes, Paradigms, and Violence Against Women. Karachi: Oxford University Press.

- Year book, 2003-2004. Global vision publishing House. New Delhi. Government of Pakistan, Ministry of Women Development.

- Year Book,(2004).Ministry of Women Development in Pakistan.

- Year Book,(2005).Ministry of Women Development in Pakistan.

- Zafar, Fareeha. (1991). Finding Our Way: Readings on Women in Pakistan. Lahore: ASR Publications.

- Zaheer \& Shamreeza. (2012).Legal Protections Provide under Pakistani Law against Anti Women Practices: Implementation Gaps between Theory and Practices.

- Zia, Taiba.(2013).Acid Violence in Pakistan, Los Angles, UCLA centre.ww.escholorship.org/ucl/item/65v95821. 